\title{
The Management of School Indiscipline in Elementary School Historical Review and Current Reality
}

\author{
Athanasios Karaffillis \\ Department of Primary Level Education, Democritus University of Thrace \\ Nea Chili, 68100, Alexandroupolis, Greece \\ Tel: 30-25510-77056 E-mail: akarafil@eled.duth.gr
}

\author{
Grigorios Doulgeris (Corresponding author) \\ Department of Primary Level Education, Democritus University of Thrace \\ Nea Chili, 68100, Alexandroupolis, Greece \\ Tel: 30-23210-46342 E-mail: gdoulger@eled.duth.gr
}

Received: October 4, 2015 Accepted: October 21, 2015 Published: October 29, 2015

doi:10.5296/jet.v3i1.8386 URL: http://dx.doi.org/10.5296/jet.v3i1.8386

\begin{abstract}
This work is a summary of the postgraduate thesis carried out at the Department of Primary Education, Democritus University of Thrace, so as to explore the issue of school indiscipline from both theoretical and empirical terms. In previous years, inappropriate behaviors were dealt with severely painful means, but at present the above methods have been banned and replaced with other interventionist actions, each of which has a different degree of efficacy to the unruly child. Lately, however, greater emphasis is given on preventing incidents of disobedience, a project that depends on various factors. Finally, research was conducted on a sample of 192 primary school teachers in the prefecture of Serres, whose answers were correlated with the variable "gender".
\end{abstract}

Keywords: school indiscipline, elementary school, addressing the past, addressing the present, prevention factors

\section{The terms of "discipline" and "classroom management"}

Etymologically, the word "discipline" is a compound noun, as it comes from two greek words that mean convince + principle, giving the meaning of obedience or allegiance to some person or some authority (Aravanis, 2000). According to Eggleton (2001), discipline is related to education, developing personalities or refining the moral and mental abilities 
through obedience to the rules and the authority (Kilimci, 2009).

In general, unruly actions of students can be summarized into three general categories:

-Excessive reactions: these are behaviors that occur in a greater extent than expected for the age of the child (stubbornness crisis, non-compliance, increased physical activity)

-Inadequate reactions: these refer to those actions that are realized at a higher frequency for this age level (deficient social skills, non-response to school study and classroom activities)

-Problems associated with controlling impulses: these regard behaviors considered appropriate within specific contexts and undesirable in some others (the banter between friends during the break compared to the banter during lessons) (Angeli \& Vlachou, 2011).

Nevertheless, this term is broad, contributing to the creation of misconceptions (Kapsalis, 2007). More specifically, both the scholastic and the academic community often use the terms "discipline" and "control of the class" as synonyms, having a special preference for the first.

The identification, though, is incorrect, because we can talk about gaining or losing control of a car, for example, but it is unlikely to talk about disciplining a mechanical device or an organism (Clark, 1998). Classroom management aims, in fact, to organize classroom activities and maintain control throughout the whole learning process. The result is to provide an environment where learning objectives can sooner or later be achieved (Moore \& Hansen, 2012)

\section{The approach of school indiscipline in the past}

\subsection{Ancient Athens \& ancient Sparta}

In the past, school life was based on a set of rules, a particular ideology and a hierarchy of relationships and people, the violation of which led to a series of sanctions, a practice that continues until today (Raptis, 1998). School discipline was considered a paramount condition for the smooth flow of teaching and it was consolidated with the absolute obedience of the students to the teachers through, mainly, the imposition of penalties (Manos, 1989).

In ancient Greece and specifically in ancient Athens, when a boy reached the age to attend school for the first time, a "pedagogue" took responsibility for his moral education. A "pedagogue" was in fact a slave, whose responsibility was to accompany the child everywhere and teach him good manners, utilizing a variety of physical punishments, quite often implemented with the use of a stick.

When the children went to the "palestra" (sports place), the tutelage was at the hands of "paidotribes" (child-former), who with a long forked walking stick aimed to restrain the inept and refractory children (Flacelière, 1970). Thus, in ancient Athens, from the first moment students started school until the very end, they were constantly getting slaps, put into practice with a stick, a rod or a whip. 
Despite that, the boys of ancient Athens felt much happier than those of Sparta who experienced very strict methods of discipline throughout the years of their education and further on (Kolobova \& Ozereckaja, 1999). Lykourgos did not depute slaves for the edification of children, but "paidonomous", i.e. people coming from senior leaders.

Their responsibilities were to gather the children in a room and supervise them, by applying very strict punishments to anyone having inappropriate behavior. If "paidonomos" was absent, then Lycurgus gave the right to any citizen that was close to the students to undertake his work (Stovaios, 1995).

\subsection{Byzantium}

The Byzantine era is characterized as the most fierce and dark one in the field of education (Giannakoulis, 2001). The painful physical punishments, like flogging, were more and more preferred by teachers to combat incidents of school defiance (Poulakou-Rempelakou, 2007). However, the punitive methods applied during the Byzantine period were not limited only to physical punishment.

Fasting was one more usual measure against the disobedient and weak in performance students, who were not allowed to leave school at noon and go home for lunch. Moreover, among the choices teachers had so as to admonish the naughty children was spitting on them, pulling their hair and smudging their faces with ink (Koukoules, 1948; Poulakou-Rempelakou, 2007).

Nonetheless, the good teacher should not always use extreme ways to ensure discipline, but choose mild disciplinary tools, too, such as admonishment. For the effectiveness of this method was necessary for the teacher to have abundant patience, to watch the tone of his voice and to avoid flattery and insults, taking care to keep control of himself (Tsampis, 1999).

\subsection{9th century in Greece}

Through a review of relevant bibliography it is observed that the Greek General Education System of the 19th century borrowed the strict pedagogical system of the past, which remained unchanged throughout all these years (Raptis, 1998). Equally painful to beating and the other physical punishments was genuflection, during which the students were forced to kneel on gravel or olive pits. This punishment was imposed so often that protective hard lumps, like the ones camels have on their knees, were created on the knees of several children (Gontikakis, 1992).

An important place in the punishments of that period possessed the well-known phalanx as well, which had a variety of shapes and sizes depending on the ingenuity of teachers and the know-how of each era (Simopoulos, 1987). The teacher tied the feet of the undisciplined child with a rope and, after twisting it in order to make it tight, he proceeded to the beating (Papadimitriou, 1950). Naturally, the student's legs swelled, blood accumulated in the head and the child, when released, resembled a corpse (Chatziioannou, 1930).

On the other side, there were also milder penalties, mainly applied in schools using peer teaching, which existed in Greece since the early $19^{\text {th }}$ century. The teacher had the option to 
choose from a variety of punitive means, such as making the undisciplined student copy texts during break, not giving any kind of reward to the student for a period of time and hanging on the child's neck a sign writing "chatty", "grimy", "disobedient", "liar", "pervert", etc., according to the disciplinary impropriety in point.

Another common penalty was making the student stand facing the wall, forced, sometimes, to stretch his/her hands upwards and stand on one leg (Boukouvalas, 1902; Lefas, 1942). Finally, one more punishment was the naughty child to hold up and with stretched hands various objects that were particularly heavy for his/her age and physique (Chatziioannou, 1930).

\section{The approach of school indiscipline today}

\subsection{Non-verbal interventions}

Every now and again, conduct problems, which consume a respectable part of teaching time, emerge, requiring to be extensively discussed and directly addressed (Kandarakis, 2004; Rothstein, 1990). "Dealing with disciplinary problems" means that the teaching staff need to use a number of techniques in order to restrain the conduct problems of students, thus restoring control of the classroom and the school in general (Kyridis, 1999).

The repression of unruly behavior is important to be established upon four basic principles: the principle of minimum intervention, the principle of discreet intervention, the principle of progressive intervention and the principle of equivalence between misconduct and intervention (Chatzopoulos, 2012). As implied in the first principle, the instructor tries the simplest disciplinary method that can be effective, while in discreet intervention he/she is required to manage deviant behavior by avoiding to address the undisciplined child in public so as not to distract the other members of the class (McDaniel, 1986; Slavin, 2006). Concerning progressive intervention, the teacher gradually increases the intensity of intervention, which, on the basis of the last principle, depends on the range of the incident in point (Chatzopoulos, 2012).

With regard to disciplinary issues of minor importance, they can be dealt with the help of non-verbal intervention strategies, which do not interrupt the flow of the lesson, prevent verbal conflict between the teacher and the children and, at the same time, give students the opportunity to self-regulate their behavior (Lampiris, 2006). The instructor can choose from a variety of non-verbal interventions, among which are planned ignoring, signal interference, proximity control and touch control (Powell \& Caseau, 2004).

To begin with, planned ignoring is based on the theory of reinforcement, according to which, if we ignore a behavior, this weakens and is gradually eliminated (Levin \& Nolan, 1991). However, when there is a behavior that puts at stake the psychophysical integrity of the child, the next technique, signal interference can come into use. What this strategy does is help the teacher send non-verbal signs to the student in order to make him/her understand that his/her behavior is not appropriate for the current circumstance (Powell \& Caseau, 2004). Examples of such signs are making gestures, frowning, coughing, shaking the head etc. (Larrivee, 2009; Redl \& Wineman, 1952). 
Certainly, there is always the possibility that the signs do not prove to be effective, leading the teacher to try the proximity control. The latter may calm down the child's restlessness or excessive enthusiasm, which may cause indiscipline and disruption of the learning process (Smith \& Laslett, 1993). Heading towards the student and staying for a while behind or next to him/her can be sufficient to put an end to an unwanted behavior (Powell \& Caseau, 2004).

In case none of the aforementioned techniques work, the teacher may try to use the technique of touch control, in which the instructor intends to bring the child back in order by giving them a light blow on the shoulder or holding them by the hand and leading them in their seat (Burden, 2000; Good \& Brophy, 1987). However, the use of this method is likely to sometimes lead to opposite to the anticipated results, since a light blow on the back or a reassuring touch may provoke anger and aggressive mood on the part of students. For this reason, the teacher must be particularly careful with the reactions of each child in order to know whether this technique serves its purpose for each student separately (Powell \& Caseau, 2004).

\subsection{Verbal interventions}

As regards school behavior problems of greater severity, the use of verbal techniques is more appropriate to restore the normal flow of the teaching process as soon as possible. Some of the verbal intervention strategies a teacher can use are:

-call the student's name during lesson and ask him/her a question

-remove seductive objects

-help the child overcome hurdles

-send an "I Message"

-use positive phrasing

-remind the rules

-appeal to the student's sense of values

-reprimand the child and request the restoration of the order in class (Good \& Brophy, 1987; Lampiris, 2006; Larrivee, 2009; Levin \& Nolan, 1991; Powell \& Caseau, 2004; Smith \& Laslett, 1993).

The first technique that suggests calling the student's name refers to the case when the teacher addresses the child who demonstrates inappropriate behavior during the lesson and poses a question related to the syllabus of the course (Levin \& Nolan, 1991). A pretty simple method of intervention is also considered the removal of seductive objects (cards, whistles, glues, water guns) that are particularly attractive to children and constantly distract their attention (Maag, 2001; Muscott, 2001). The confiscation of such objects aims at making the student pay attention to the lesson again, but, if this is done arbitrarily and suddenly, then it may sometimes lead to student-teacher conflicts (Larrivee, 2009). 
In addition, the instructor can help the children whose inability to solve a specific exercise in class frustrates them, having as a result to abandon their effort and start talking to their classmates or writing aimlessly in their notebook (Maag, 2001). Sending an "I Message" can also be a useful tool that is systematically used in Gordon's discipline model. He uses this term to highlight how necessary it is for disobedient students to understand the impact of improper conduct on the other children since they are not sometimes aware of the seriousness of the situation (Matsangouras, 2005).

At the opposite end of the previous strategy, the teacher attempts to use positive phrasing when addressing the unruly child in an effort to demonstrate the benefits the student will reap if he/she complies with the rules (Levin \& Nolan, 1991). To this end, reminding the rules applicable to all members of the class can be of great help. In case, for example, some student speaks without permission during the lesson, the rule that "every time we want to say something in class, we raise our hand and wait to be given permission by the teacher" can be reminded (Chatzopoulos, 2012: 181).

If the above method does not improve the situation, the instructor can appeal to the child's moral values, like the sense of cooperation, honesty and politeness (Smith \& Laslett, 1993). It is worth mentioning that the effectiveness of "appealing" lies on using it in moderation, and not too often, as it has been found to happen in school reality (Redl \& Wineman, 1952).

The last option among the various verbal interventions is reprimanding the child and requesting the restoration of the order in class, in which cases the teacher asks directly the student to stop any inappropriate behavior and return actively to the teaching process (Burden, 2000). Nonetheless, the instructor should bear in mind that reprimanding the children and giving orders may sometimes cause greater disobedience, as the students who often show signs of misconduct rarely reform when teachers treat them with toughness (Lewis, 2001).

\subsection{The ecosystemic approach}

An alternative to the diverse strategies against school disorder appears to be the ecosystemic approach. It is based on the perception that the origins and aims of human behavior are interactive and it considers the undesired actions as a part of the social background in which they appear (Cooper \& Upton, 1990; Karantzis, 2011).

Thus, the teacher that cares to approach the conduct problem of a student ecosystemically focuses not only to the problem itself but, at the same time, explores the links between the unruly behavior and the factors of the system within which it unfolds (Kyriazi, 2010). First of all, the teacher seeks to understand what lies behind the deviance, focusing on chronic situations that are predictable and possible to appear. Then, he/she proceeds to a self-reflection of the methods of intervention he/she has used and their expected results, attempting to give his/her own interpretation of the situation and assessing its severity (Tyler \& Jones, 1998).

In the final stage, it is attempted to deal with the misconduct via the different techniques the ecosystemic approach offers (Cooper \& Upton, 1990). The most famous one is that of reframing, which suggests altering the framework of the unwanted behavior and integrating it 
in a new context, resulting, thus, in the change of its entire meaning (Paritsis, Lampidi, \& Todoulou, 1999).

\section{Factors preventing student misbehavior}

\subsection{The personality and the leadership style of the teacher}

In recent years, educational research has shifted its focus from the repression of unwanted student actions to the strategies that contribute to their prevention (Kolympari \& Seferiadou, 2012). Addressing the problems of discipline in schools is definitely important and necessary, but it is of greater significance to avoid any inappropriate deeds that can disrupt the normal flow of the lesson (Katsamagkou, 2004).

The teacher himself/herself, with his/her own and unique personality and behavior, in correlation with the atmosphere he/she has created in class, can play a very crucial role in the prevention of improper actions. In particular, in managing to keep control of the class it is necessary for the instructor to display certain leading abilities including consistency, determination, impartiality and accurate assessment of people and situations (Fontana, 1996 ${ }^{\mathrm{a}}$ ). Children also accept the teacher that shows confidence towards them, accepting the positives and negatives of their character and helping them, at the same time, eliminate their difficulties (Chatzidimou, 2007).

In addition, students tend to characterize as "good" a kind, friendly and smiling teacher who cooperates with them, answers their questions effectively and shapes a cheerful atmosphere in class (Anagnostopoulou, 2008). Obviously, humor is one more asset a teacher might have, which constitutes an integral part of daily life and gives children the opportunity to see him/her as their ally (Taratori, Konsolas, \& Kougiourouki, 2007).

Depending on the behavior each teacher demonstrates, he/she is described, according to bibliography, as democratic, authoritarian or indifferent. Authoritarian is considered to be the instructor that determines and controls all the activities that take place in the classroom, whereas democratic is the one who constantly collaborates with the children, encouraging them to take part in the design and the process of teaching (Fragkos, 1977; Pyrgiotakis, 2000).

The third characterization is, subsequently, given to instructors who maintain a passive approach towards everything that happens during the lesson; neither praising children nor punishing them for their misdeeds (Chatzidimou, 2010). Research has shown that indifferent teacher guidance causes tension and a mess, while the bossy way of action increases the student's performance, but causes a negative team atmosphere and frustration. On the contrary, the democratic way of action assists in achieving the learning goals, without creating the aforementioned negative atmosphere, even when the teacher is absent from the classroom (Schunk, Pintrich, \& Meece, 2010).

The personality and behavior of the instructor are in direct connection with the atmosphere in class, which consists of teacher-student and student-student interpersonal relationships (Fotopoulou \& Baralos, 2010). A pleasant environment in the classroom is a great 
achievement because it leads to a positive disposition towards school on the part of the students, while the reason for a negative attitude may lie to an emotionally charged atmosphere (Petroulakis, 1992).

\subsection{The classroom climate}

The prevalence of a negatively charged atmosphere results in the existence of friction in teacher-student relationships, which is likely to arise from the teacher's failure to meet the requirements of his/her role as mediator. He/she is, namely, expected to intermediate between two generations with different opinions and perceptions, trying to connect the past with the present or the future, in order to mitigate as much as possible the crisis in his/her communication with the students (Xochellis, 1989). When, in fact, he/she manages to have a good relationship with the children, he/she should try even more to protect it from decaying. (Ntraikors, Gkrangouolnt, \& Pepper, 1989).

Equally important is the teacher to make sure that there are good inter-student relationships and try to reinforce them, since they contribute to the children's moralization and socialization (Tsourekis, 1987). A useful tool to the achievement of this purpose are sociograms through which the instructor can distinguish the groups students formed in between them, the leaders of each group and the children who get excluded from these groups and remain isolated (Charalampopoulos, 1993).

\subsection{Lesson planning and teacher training}

In the context of student indiscipline prevention, both lesson planning and teacher training play a key role. A prerequisite for an effective lesson planning is the instructor to be thoroughly knowledgeable of what is to be taught, thus ensuring that the students will be given the motives they need to be greatly involved in the learning process (Charalampakis, 1984). As a result, students are rarely likely to disturb the class because they are busy dealing with various educational activities (Fragkos, 1977).

While designing his/her lesson plan, the teacher should select among a variety of teaching methods, with a view to achieving the greatest possible active participation of the children (Pigiaki, 1999). The fact that the course should be well-structured does not certainly limit the obligations a teacher has to the previously mentioned points. He/ she should also ensure the existence of the necessary quantity of materials required for the various activities, like scissors or pencils, as well as the access to and availability of any audiovisual equipment needed (Fontana, 1996 ${ }^{\mathrm{a}}$ ).

High quality undergraduate studies can definitely prove to be very helpful to a correct and complete lesson planning. Yet, most universities are engaged purely with teaching and they barely prepare future teachers to prevent and deal with school indiscipline (Matsangouras, 2005; Matsopoulos, 2009). As a result, the majority were introduced into the profession without having been trained to deal with classroom management and ways to repel and stop any behavior problems children may have (Anagnostopoulou, 2008). 
In addition, beyond basic education, the training any teacher gets later on in his/her life can play an active role in the prevention and extinction of inappropriate student actions. However, if his/her education is inadequate, then the development of false opinions or even biases about school performance and child behavior is quite possible, aggravating, thus, the existing situation (Martin, Linfoot, \& Stephenson, 1999; Xochellis, 1981).

\subsection{The school director}

The responsibility to prevent student disobedience burdens, among others, the school director too, who nowadays has a broadened role, as the needs and requirements of children, teachers and society in general have risen (Kirkigianni, 2011). Among the duties he/she undertakes is to create a positive school atmosphere that will be the result of a good and constructive cooperation of the director himself/herself with the instructors, the students and their parents (Pasiardis, 2004).

The development, in particular, of good interpersonal relationships with the teaching personnel and the students presupposes the Director to respect the personality of all of them, without exception, adhere to a single approach and treatment towards them and stand as a helper to the personal problems sometimes encountered (Maroudas \& Beladakis, 2006). As for the principal's communication and relationship with the students, giving them the right to participate in the school activities with an institutionalized and systematic way can have positive results.

It has been observed that in the school units with increased student participation there are fewer conflicts between teachers and children and there is less wear and mess (Matsangouras, 2005). Consequently, when the children's point of view is taken into account, letting them participate in the formation of rules and tasks, then they respect the school and show an active attitude towards it (Charalampakis, 1984).

\subsection{Students' parents}

The active presence and contribution of parents to the avoidance of unwanted student actions is very essential since, from a pedagogical perspective, they should not be restrained to the creation and maintenance of a safe home environment for their children (Fontana, 1996 ${ }^{\mathrm{b}}$ ). The importance of parental participation in school activities is stressed, inter alia, by the fact that it was one of the "National Goals 2000" of the American Educational System, according to which, each school unit should reinforce the involvement of parents in its processes in order to ensure that the students' school and social performance is advancing (Matsopoulos, 2005).

A number of surveys have documented that the involvement of parents in school reality rekindles the children's enthusiasm to learn and work, thus increasing the effort they make (Gkousia-Rizou, 2006). More importantly, as Hansen (1986) suggests, children should receive the same messages concerning behavior and school performance models from both their parents and their teachers (Matsopoulos, 2005). 
4.6 The technical infrastructure of the school and the classroom

Undoubtedly, it is necessary to take into account the classroom and school technical infrastructure so as to prevent student defiance. A cozy, pleasant and supportive school space provides a feeling of security among children, passing the message that they are active and appreciable members of the school (Gkousia-Rizou, 2006). For instance, the creation of such a place can be achieved by replacing the old frames from the walls of the school corridors and changing the dull colors to brighter and more pleasant ones (Grey, 2004).

Also, a sufficiently illuminated, ventilated, heated and furnished classroom with appropriate decoration and seating arrangement is a prerequisite for a comfortable and delightful school experience (Petroulakis, 1992). Nevertheless, even if all of the above apply, incidents of student deviance will continue to exist if schools continue to have cramped classes (Papadopoulos, 1991).

\section{Method}

\subsection{Aims and objectives}

The aim of this research is to explore the opinions and actions of teachers towards the phenomenon of indiscipline at school.

The research objectives are concerned with the study of the following:

a) delineation and frequency of school indiscipline

b) causes of unruly child behavior

c) strategies and methods of dealing with improper student actions

d) strategies preventing student indiscipline

e) the degree of divergence of attitudes teachers have towards children's disobedience depending on their gender

\subsection{Sample}

The research population of this study is the whole of primary school teachers. The target population was practicing teachers working in public primary schools in the Prefecture of Serres and from their total a random sample of 250 people was selected through systematic sampling.

The application of this method requires a list with the names of the target population, which for the present investigation was provided by the head of primary education in Serres, by request. The people were then ranked according to the alphabetical order of their last name and those that were multiples of the number 3 were selected.

Systematic sampling was adopted due to the fact that this method is usually used when the number of participants exceeds 100. Also, if the subjects are distributed on the basis of the alphabetical order of their surname, the sample is regarded equally representative to the one chosen through simple random sampling (Vamvoukas, 1993). 


\subsection{Research tool}

The research tool chosen to carry out this work is structured questionnaire, because it allows the collection of information from a large sample in a short time. Furthermore, the absence of the researcher during the time the sample group was dealing with the questionnaires enhances the chances to receive honest answers from the respondents (Vamvoukas, 1993).

On the other hand, one of the major disadvantages of this research tool is its partial return (Paraskevopoulos, 1993 ${ }^{\mathrm{b}}$ ). However, this was avoided in the specific search, as far as possible, with the distribution of questionnaires by the researcher himself and frequent reminders to the participants for their timely completion.

What is more, before distributing the final version of the questionnaire, there was applied preliminary research in 20 primary education teachers, who were selected after a draw. In particular, they were asked to criticize the questions and the general picture of the questionnaire with a view to improving it.

Overall, 250 questionnaires were handed out, 192 of which were returned, a number that equals with $76.8 \%$ of the initial sample. Finally, the program SPSS Statistics 17.0 was used for the calculation of the percentage corresponding to the relevant answers of each question, as well as the investigation of the degree of their diversification depending on the gender of the teacher.

\section{Presentation of results ${ }^{1}$}

\subsection{General findings}

The sample of this survey were mainly women 41-50 years old, teaching more than 21 years, almost half of which are graduates of Pedagogical Academies and the other half are graduates of University Departments of Primary Level Education. In addition, the recurrent training most subjects of the present study have had is follow-up seminars in various Regional Training Centers.

Table 1. "How often do instances of undisciplined behavior take place in your classroom?"

\begin{tabular}{|c|c|c|c|c|}
\hline Never (\%) & Seldom (\%) & Sometimes (\%) & Often (\%) & Very often (\%) \\
\hline 2.6 & 64.6 & 28.1 & 3.6 & 1 \\
\hline
\end{tabular}

Table 2. "What are the main types of undisciplined student behavior, in your opinion?"

\begin{tabular}{|l|c|}
\hline $\mathrm{He} /$ she does not pay attention during the lesson & $8.3 \%$ \\
\hline $\mathrm{He} / \mathrm{she}$ bedevils his/her classmates & $7.3 \%$ \\
\hline $\mathrm{He} / \mathrm{she}$ has an obscene and violent behavior towards the other students & $45.3 \%$ \\
\hline $\mathrm{He} / \mathrm{she}$ is rude and disobedient towards the teacher & $19.3 \%$ \\
\hline $\mathrm{He} / \mathrm{she}$ does not start or does not complete his/her assignments & $6.3 \%$ \\
\hline $\mathrm{He} /$ she is unaccountably absent or late for class & $3.6 \%$ \\
\hline $\mathrm{He} /$ she steals or destroy things & $9.9 \%$ \\
\hline
\end{tabular}

\footnotetext{
${ }^{1}$ The tables presented in the current and the next section are indicative of the tables included in the postgraduate thesis.
} 
Table 3. "According to your beliefs, who or what is to blame for student misconduct?"

\begin{tabular}{|l|c|c|c|c|c|}
\hline & $\begin{array}{c}\text { Not at all } \\
(\boldsymbol{\%})\end{array}$ & $\begin{array}{c}\text { A little } \\
(\boldsymbol{\%})\end{array}$ & $\begin{array}{c}\text { Quite } \\
(\boldsymbol{\%})\end{array}$ & $\begin{array}{c}\text { A lot } \\
(\boldsymbol{\%})\end{array}$ & $\begin{array}{c}\text { Quite a lot } \\
(\boldsymbol{\%})\end{array}$ \\
\hline A school in a noisy area & 11.5 & 44.8 & 28.1 & 13 & 2.6 \\
\hline $\begin{array}{l}\text { Shortage of technical } \\
\text { infrastructure }\end{array}$ & 17.7 & 38.5 & 29.2 & 12 & 2.6 \\
\hline $\begin{array}{l}\text { School and classroom } \\
\text { aesthetics }\end{array}$ & 10.9 & 41.1 & 32.3 & 14.1 & 1.6 \\
\hline The school headmaster & 16.1 & 22.9 & 34.4 & 22.4 & 4.2 \\
\hline Syllabus & 10.4 & 28.1 & 30.2 & 26.6 & 4.7 \\
\hline Layout of desks & 8.3 & 27.1 & 42.7 & 20.3 & 1.6 \\
\hline $\begin{array}{l}\text { A big number of students in } \\
\text { the classroom }\end{array}$ & 1.6 & 4.2 & 14.6 & 35.4 & 44.3 \\
\hline
\end{tabular}

Table 4. "How much do you consider the following factors cause the inappropriate behavior of the students?"

\begin{tabular}{|l|c|}
\hline The student & $13 \%$ \\
\hline The teacher & $1 \%$ \\
\hline The school & $6.8 \%$ \\
\hline The family & $66.7 \%$ \\
\hline The Media and the Internet & $12.5 \%$ \\
\hline
\end{tabular}

Table 5. "To what extent do you regard that the following factors contribute to school indiscipline?"

\begin{tabular}{|l|c|c|c|c|c|}
\hline & $\begin{array}{c}\text { Not at } \\
\text { all (\%) }\end{array}$ & $\begin{array}{c}\text { A little } \\
(\mathbf{\%})\end{array}$ & $\begin{array}{c}\text { Quite } \\
(\%)\end{array}$ & $\begin{array}{c}\text { A lot } \\
(\%)\end{array}$ & $\begin{array}{c}\text { Quite a } \\
\text { lot (\%) }\end{array}$ \\
\hline Poorly qualified teacher & 8.9 & 23.4 & 37 & 22.9 & 7.8 \\
\hline Non-adapted lesson & 0.5 & 11.5 & 35.9 & 38 & 14.1 \\
\hline Poor interpersonal relationships & 1 & 7.8 & 39.1 & 38.5 & 13.5 \\
\hline Authoritarian or indifferent teacher & 1 & 7.3 & 25.5 & 37 & 29.2 \\
\hline $\begin{array}{l}\text { Insufficient teacher recurrent } \\
\text { training }\end{array}$ & 10.4 & 24 & 37.5 & 22.4 & 5.7 \\
\hline $\begin{array}{l}\text { Monotony in the use of teaching } \\
\text { aids and teaching methods }\end{array}$ & 0.5 & 21.4 & 43.8 & 30.2 & 4.2 \\
\hline $\begin{array}{l}\text { Insufficient teacher preparation for } \\
\text { the lesson }\end{array}$ & 4.7 & 18.2 & 36.5 & 26.6 & 14.1 \\
\hline
\end{tabular}


Table 6. "In which of the following conditions have you observed the existence of unwanted deeds?"

\begin{tabular}{|c|c|c|}
\hline Boy & Girl & Both \\
\hline $70.8 \%$ & $1.6 \%$ & $27.6 \%$ \\
\hline Young children & Older children & Both \\
\hline $8.9 \%$ & $36.5 \%$ & $54.7 \%$ \\
\hline High school performance & Low school performance & Both \\
\hline $1 \%$ & $58.9 \%$ & $40.1 \%$ \\
\hline High socio-economic background & Low socio-economic background & Both \\
\hline $6.8 \%$ & $31.3 \%$ & $62 \%$ \\
\hline Difficult, demanding subjects & Easy subjects & Both \\
\hline $37 \%$ & $6.8 \%$ & $56.3 \%$ \\
\hline Morning hours & Noon hours & Both \\
\hline- & $56.3 \%$ & $43.8 \%$ \\
\hline
\end{tabular}

Table 7. "How often do you apply the following practices in class in order to prevent possible undesirable behavior?"

\begin{tabular}{|l|c|c|c|c|c|}
\hline & $\begin{array}{c}\text { Never } \\
(\mathbf{\%})\end{array}$ & $\begin{array}{c}\text { Seldom } \\
(\mathbf{\%})\end{array}$ & $\begin{array}{c}\text { Sometimes } \\
(\mathbf{\%})\end{array}$ & $\begin{array}{c}\text { Often } \\
(\mathbf{\%})\end{array}$ & $\begin{array}{c}\text { Very } \\
\text { often }(\boldsymbol{\%})\end{array}$ \\
\hline Praise & - & 2.6 & 17.2 & 52.6 & 27.6 \\
\hline Supervision & - & 2.1 & 16.7 & 57.8 & 23.4 \\
\hline Material reward & 17.2 & 25 & 26.6 & 22.9 & 8.3 \\
\hline Positive remarks & - & 2.1 & 16.1 & 51 & 30.7 \\
\hline Introduce rules & 0.5 & 2.6 & 19.8 & 42.2 & 34.9 \\
\hline $\begin{array}{l}\text { Use of various teaching } \\
\text { aids and methods }\end{array}$ & 0.5 & 6.3 & 37.5 & 41.7 & 14.1 \\
\hline Discussion & - & 3.6 & 14.1 & 40.1 & 42.2 \\
\hline Approval & 3.1 & 9.4 & 15.6 & 42.2 & 29.7 \\
\hline High marks & 5.7 & 20.3 & 30.7 & 29.7 & 13.5 \\
\hline Award a prize & 22.9 & 29.7 & 19.8 & 17.2 & 10.4 \\
\hline
\end{tabular}

Table 8. "How often do you resort to the following practices in order to handle the problems caused by your students' unsuitable actions in class?"

\begin{tabular}{|l|c|c|c|c|c|}
\hline & $\begin{array}{c}\text { Never } \\
(\mathbf{\%})\end{array}$ & $\begin{array}{c}\text { Seldom } \\
(\mathbf{\%})\end{array}$ & $\begin{array}{c}\text { Sometimes } \\
(\mathbf{\%})\end{array}$ & $\begin{array}{c}\text { Often } \\
(\mathbf{\%})\end{array}$ & $\begin{array}{c}\text { Very often } \\
(\mathbf{\%})\end{array}$ \\
\hline $\begin{array}{l}\text { Derivation of pleasant } \\
\text { activities }\end{array}$ & 34.9 & 37.5 & 16.7 & 8.3 & 2.6 \\
\hline Discussion & 0.5 & 2.6 & 10.9 & 51 & 34.9 \\
\hline Threat & 35.9 & 45.3 & 14.1 & 4.2 & 0.5 \\
\hline Reprimand & 4.7 & 40.6 & 42.2 & 9.4 & 3.1 \\
\hline Change of seating & 4.2 & 24 & 43.2 & 23.4 & 5.2 \\
\hline Deliberate indifference & 16.1 & 34.9 & 39.1 & 7.3 & 2.6 \\
\hline $\begin{array}{l}\text { Referral to the } \\
\text { headmaster }\end{array}$ & 43.8 & 42.2 & 9.9 & 4.2 & - \\
\hline Advice & 2.6 & 29.7 & 38.5 & 20.8 & 8.3 \\
\hline Brief to the parents & 1 & 12.5 & 35.9 & 38 & 12.5 \\
\hline Written punishment & 70.3 & 24.5 & 4.2 & 1 & - \\
\hline
\end{tabular}




\subsection{Correlation based on the gender of teachers}

All of the variables studied are categorical and, therefore, in order to investigate their correlation with the gender of teachers, $\mathrm{X}^{2}$ test was used to determine if there is independence from each other. The cases studied with this test are:

$\mathrm{H}_{0}$ : there is independence between variables

$\mathrm{H}_{1}$ : no independence between variables

So as to reject the statistical hypothesis $\mathrm{H}_{0}$, the possibility p-value needs to be less than 0.05 , i.e. $\mathrm{p}$-value $<0.05$. A basic condition to accept the reliability of the test is a maximum of $25 \%$ of the cells to have expected frequency less than 5 .

Conducting the test $\mathrm{X}^{2}$ with the help of SPSS, the following results were given:

Table 1. Temperament

\begin{tabular}{|l|c|c|c|c|c|}
\hline & Not at all (\%) & A little (\%) & Quite (\%) & A lot (\%) & Quite a lot (\%) \\
\hline Male teachers & - & 7.4 & 38.3 & 37 & 17.3 \\
\hline Female teachers & 1.8 & 2.7 & 22.5 & 39.6 & 33.3 \\
\hline Total & 1 & 4.7 & 29.2 & 38.5 & 26.6 \\
\hline
\end{tabular}

Table 2. Effectiveness of the rewards

\begin{tabular}{|l|c|c|c|c|c|}
\hline & Very low (\%) & Low (\%) & Moderate (\%) & High (\%) & Very high (\%) \\
\hline $\begin{array}{l}\text { Male } \\
\text { teachers }\end{array}$ & 4.9 & 29.6 & 30.9 & 24.7 & 9.9 \\
\hline Female teachers & 6.3 & 10.8 & 47.7 & 21.6 & 13.5 \\
\hline Total & 5.7 & 18.8 & 40.6 & 22.9 & 12 \\
\hline
\end{tabular}

Table 3. Teacher using humor in class

\begin{tabular}{|l|c|c|c|c|c|}
\hline & $\begin{array}{c}\text { Not at all } \\
(\boldsymbol{\%})\end{array}$ & A little (\%) & Quite (\%) & $\begin{array}{c}\text { A lot } \\
(\%)\end{array}$ & $\begin{array}{c}\text { Quite a lot } \\
(\%)\end{array}$ \\
\hline Male teachers & $1.2 \%$ & $11.1 \%$ & $19.8 \%$ & $34.6 \%$ & $33.3 \%$ \\
\hline Female teachers & $0.9 \%$ & $4.5 \%$ & $14.4 \%$ & $37.8 \%$ & $42.3 \%$ \\
\hline Total & $1 \%$ & $7.3 \%$ & $16.7 \%$ & $36.5 \%$ & $38.5 \%$ \\
\hline
\end{tabular}

\section{Conclusions}

As the research results show, primary school teachers in the Prefecture of Serres support that the predominant expressions of deviant student behavior are violence and aggression. Furthermore, they argue that the incidents of indiscipline are most commonly detected among boys and appear in low frequency in their class, which does not mean, though, that they are not serious.

According to the teachers' opinion, the main factor to blame for school disorder is the family of the children. Nonetheless, they also recognize the influence other factors can have, such as 
the inadequacy in school technical infrastructure, cramped classrooms, the poor teacher-student and student-student relationships, as well as the authoritarian and indifferent behavior of the teacher.

In order to prevent student disobedience, instructors try to characterize the children positively and discuss the issue with them. When, however, undesired actions already exist, they either discuss the problem with the naughty student or inform his/her parents about it. Additionally, the practices mentioned to be generally used during teaching encourage children to take initiative and support them when they have problems.

When approaching the phenomenon of school indiscipline in relation to the gender of teachers, it was observed that women consider rewards effective more than men do, mostly resorting to praises or prizes and the use of rich teaching aids and methods. Also, female teachers feel more strongly that humor on the part of the instructor is an important factor in favor of the prevention of inappropriate student actions and they tend to change seating in order to control the naughty behavior of some children.

As regards the reasons for the emergence of the various cases of school defiance, female teachers blame difficult student temperament more than their male colleagues do. The same is true for the fruitless cooperation between the instructor and the school counselor, as well as the lack of classroom management courses during teachers' undergraduate studies.

\section{Suggestions}

Lastly, what would be of particular interest in possible future studies is to explore the various aspects of school indiscipline by associating them with the teachers' age and years of service, since over time the beliefs and ways to manage this phenomenon are very likely to change. Also, a very worthwhile venture would be a part of or the whole of the research population in a related future work to be comprised of teachers from the field of special education in order to examine this issue from the perspective of their own thoughts, opinions and reports.

\section{References}

Anagnostopoulou, M. S. (2008). To zitima tis peitharchias stin Ekpaidefsi: Symvoli stin prolipsi tis apeitharchis symperiforas ton mathiton [The issue of discipline in Education: Contribution to the prevention of unruly student behavior]. Thessaloniki: Adelfon Kyriakidi.

Angeli, K., \& Vlachou, M. (2011). Technikes kai methodoi antimetopisis provlimaton stin taxi [Techniques and troubleshooting methods in the classroom]. Sto M. Zafeiropoulou \& A. Kalantzi-Azizi (Epim.), Prosarmogi sto scholeio: Prolipsi kai antimetopisi dyskolion (pp. 89-157). Athina: Pedio.

Aravanis, G. E. (2000). Peitharchia kai ekpaidefsi: O rolos ton poinon kai ton amoivon sto scholeio kai sto nipiagogeio [Discipline and training: The role of penalties and praises at school and kindergarten]. Athina: Grigori.

Boukouvalas, G. A. (1902). Epetiris tis dimotikis ekpaidefseos: etos A' (1901-1902) [Yearbook of primary education: year A' (1901-1902)]. Athina: Konstantinidou. 
Burden, P. R. (2000). Powerful Classroom Management Strategies: Motivating Students to Learn. Thousand Oaks, California: Sage.

Charalampakis, V. Ch. (1984). Geniki paidagogiki [General pedagogy]. Athina.

Charalampopoulos, V. I. (1993). Organosi tis didaskalias kai tis mathisis genika. Didaktiki methodologia. [Organization of teaching and learning in general. Teaching methodology]. Athina: Gutenberg.

Chatzidimou, D. Ch. (2007). Eisagogi stin Paidagogiki: Symvoli sti diachysi tis paidagogikis skepsis [Introduction to Pedagogy: Contribution to the diffusion of pedagogical thought]. Thessaloniki: Adelfon Kyriakidi.

Chatzidimou, D. Ch. (2010). Eisagogi sti Thematiki tis Didaktikis: Symvoli sti theoria kai stin praxi tis didaskalias [Introduction to the Issue of Teaching: Contribution to the theory and practice of teaching]. Thessaloniki: Adelfon Kyriakidi.

Chatziioannou, I. Ch. (1930). Panellinion lefkoma ethnikis ekatontaetiridos 1821-1921: $i$ chrysi vivlos tou ellinismou [Panhellenic album of national century 1821-1921: the golden bible of Hellenism]. Tomos E'. Athina: Nea Elliniki Ios.

Chatzopoulos, D. (2012). Didaktiki fysikis agogis [Didactics of physical education]. Thessaloniki: Panepistimio Makedonias.

Clark, C. (1998). Discipline in schools. British Journal of Educational Studies, 46(3), 289-301. http://dx.doi.org/10.1111/1467-8527.00085

Cooper, P., \& Upton, G. (1990). An Ecosystemic Approach to Emotional and Behavioural Difficulties in Schools. Educational Psychology, 10(4), 301-321. http://dx.doi.org/10.1080/01 44341900100402

Flacelière, R. (1970). O dimosios kai idiotikos vios ton archaion Ellinon [The public and private life of ancient Greeks]. Athina: Papadima.

Fontana, D. (1996 ). O Ekpaideftikos stin taxi [The teacher in class]. Athina: Savvalas.

Fontana, D. $\left(1996^{\mathrm{b}}\right)$. Psychologia gia Ekpaideftikous [Psychology for Teachers]. Athina: Savvalas.

Fotopoulou, Ch., \& Baralos, G. (2010). Oi diaprosopikes scheseis ekpaideftikon-mathiton sti scholiki taxi kai o rolos tou ekpaideftikou sti diamorfosi tous [Interpersonal teacher-student relationships in the classroom and the teacher's role in shaping them]. Sto N. Th. Georgiadis, K. Sarafidou \& P. A. Demiroglou (Epim.), O Ekpaideftikos kai to ergo tou: Parelthon - Paron - Mellon (pp. 669-684). Praktika $3^{\text {ou }}$ Panelliniou Synedriou ETEAD. Tomos A'. Drama: Etaireia Epistimon Agogis.

Fragkos, Ch. P. (1977). Psychopaidagogiki - Themata paidagogikis psychologias, paideias, didaktikis kai mathisis [Psycho-pedagogy - Issues of pedagogical psychology, education, teaching and learning]. Athina: Papazisi. 
Giannakoulis, N. (2001). I Somatiki Poini sto Scholeio [Corporal Punishment at School]. Ta Ekpaideftika, 61-62, 236-243.

Gkousia-Rizou, M. (2006). Scholiki pragmatikotita: Pos na antimetopisete me epitychia tis dyskolies stin taxi [School reality: How to troubleshoot successfully the difficulties in the classroom]. Athina: Livani.

Gontikakis, S. K. (1992). I paideia stin Kriti (1878-1889) [Education in Crete (1878-1889)]. Irakleio: Vikelaia vivliothiki \& Dimos Irakleiou.

Good, T., L., \& Brophy, J. E. (1987). Looking in Classrooms. New York: Harper \& Row.

Grey, D. (2004). To egkolpio tou ekpaideftikou [The teacher's handbook]. Athina: Savvalas.

Kandarakis, A. G. (2004). Synyparchoun oi Mathisiakes Dyskolies me ta Provlimata Symperiforas? [Do Learning Difficulties coexist with Behavior Problems?]. Athina: Savvalas.

Kapsalis, A. G. (2007). Paidagogiki psychologia [Pedagogical psychology]. Thessaloniki: Adelfon Kyriakidi.

Karantzis, I. D. (2011). O Daskalos sti Scholiki Taxi: vasikes psycho-paidagogikes \& didaktikes efarmoges [The Teacher in the Classroom: basic psycho-pedagogical \& teaching applications]. Athina: Ion.

Katsamagkou, M. V. (2004). Protaseis gia tin prolipsi tis provlimatikis - apeitharchis symperiforas ton mathiton mesa sti scholiki aithousa apo tous ekpaideftikous [Proposals for the prevention of problematic - unruly behavior of students in the classroom by teachers]. $\mathrm{Ta}$ Ekpaideftika, 73-74, 112-118.

Kilimci, S. (2009). Teachers' perceptions on corporal punishment as a method of discipline in elementary schools. The Journal of International Social Research, 2(8), 242-251.

Kirkigianni, F. P. (2011). O Apotelesmatikos Diefthyntis tou Scholeiou [The Effective School Director]. Ta Ekpaideftika, 99-100, 96-113.

Kolobova, K. M., \& Ozereckaja, E. L. (1999). I kathimerini zoi stin archaia Ellada [Everyday life in ancient Greece]. Athina: Papadima.

Kolympari, S., \& Seferiadou, V. (2012). Nai stin timoria i stin peitharchia??? [Yes in punishment or in discipline???]. Anoichto Scholeio, 1-5.

Koukoules, F. I. (1948). Vyzantinon vios kai politismos [Byzantine life and culture]. Tomos A'. Athina: Myrtidi.

Kyriazi, O. (2010). I oikosystimiki prosengisi [The ecosystemic approach]. Sto E. A. Koliadis (Epim.), Symperifora sto scholeio: Axiopoioume dynatotites, Antimetopizoume provlimata (pp. 211-224). Athina: Grigori.

Kyridis, A. G. (1999). I peitharchia sto Scholeio. Theoria kai Erevna [Discipline at School. Theory and Research]. Athina: Gutenberg. 


\section{Macrothink Institute ${ }^{\mathrm{TM}}$}

Lampiris, G. A. (2006). Provlimata symperiforas stin taxi. Stratigikes prolipsis kai stratigikes antimetopisis [Behavior problems in the classroom. Prevention strategies and treatment strategies]. Epistimoniko Vima tou Daskalou, 5, 57-65.

Larrivee, B. (2009). Authentic Classroom Management: Creating a Learning Community and Building Reflective Practice. Upper Saddle River, NJ: Pearson.

Lefas, Ch. V. (1942). Istoria tis ekpaidefseos [History of education]. Athina: Organismos Ekdoseos Scholikon Vivlion.

Levin, J., \& Nolan, J. F. (1991). Principles of classroom management: a hierarchical approach. Englewood Cliffs, NJ: Prentice Hall.

Lewis, R. (2001). Classroom discipline and student responsibility: the students' view. Teaching and Teacher Education, 17(3), 307-319. http://dx.doi.org/10.1016/S0742-051 $\mathrm{X}(00) 00059-7$

Maag, J. W. (2001). Management of Surface Behavior: A New Look at an Old Approach. Counseling and Human Development, 33(9), 1-10.

Manos, K. G. (1989). Geniki didaktiki [General didactics]. Athina: Grigori.

Maroudas, I. G., \& Beladakis, M. D. (2006). Ta dikaiomata tou paidiou, to scholiko klima kai $i$ Aftarchiki Agogi tou A. S. Neil [The rights of the child, the school climate and the Authoritarian Treatment of A.S. Neil]. Athina: Metaspoudi.

Martin, A. J., Linfoot, K., \& Stephenson, J. (1999). How teachers respond to concerns about misbehavior in their classroom. Psychology in the Schools, 36(4), 347-358. http://dx.doi.org/10.1002/(SICI)1520-6807(199907)36:4<347::AID-PITS7>3.0.CO;2-G

Matsangouras, I. G. (2005). I scholiki taxi: Choros, Omada, Peitharchia, Methodos [The classroom: Place, Team, Discipline, Method]. Athina: Grigori.

Matsopoulos, A. (2005). Scholiki Psychologia, mia Nea Epistimi: Efarmoges sti Sygchroni Ekpaidefsi [School Psychology, a New Science: Applications in Modern Education]. Athina.

Matsopoulos, A. (2009). Epithetikotita kai via sta scholeia: stratigikes antimetopisis [Aggression and violence at schools: treatment strategies]. The art of crime, 11. Retrieved on July $20^{\text {th }}, 2014$, from http://pelop.pde.sch.gr/via/er/epi8etikotitakaivia.pdf

McDaniel, T. R. (1986). A Primer on Classroom Discipline: Principles Old and New. Phi Delta Kappan, 68(1), 63-67.

Moore, K. D., \& Hansen, J. (2012). Effective Strategies for Teaching in K-8 Classrooms. Thousand Oaks, California: Sage.

Muscott, H. S. (2001). Service-Learning and Character Education as "Antidotes" for Children with Egos That Cannot Perform. Reclaiming Children and Youth, 10(2), 91-99.

Ntraikors, R., Gkrangouolnt, B. B., \& Pepper, F. C. (1989). Diatirontas tin isorropia stin taxi: I metavasi apo to aftarchiko sto dimokratiko scholeio [Keeping balance in the classroom: The 
transition from authoritarian to democratic school]. Athina: Thymari.

Papadimitriou, S. N. (1950). Istoria tou dimotikou mas scholeiou: meros A' (1834-1895) [History of our elementary school: part A' (1834-1895)]. Athina.

Papadopoulos, N. G. (1991). Psychologia: Sygchrona themata [Psychology: Contemporary issues]. Athina.

Paraskevopoulos, I. N. $\left(1993^{\mathrm{b}}\right)$. Methodologia Epistimonikis Erevnas [Methodology of Scientific Research]. Tomos 2. Athina.

Paritsis, N., Lampidi, A., \& Todoulou, M. (1999). Systimiki prosengisi [Systemic approach]. Sto I. N. Nestoros (Epim.), I epithetikotita stin oikogeneia, sto scholeio kai stin koinonia (pp. 271-280). Athina: Ellinika Grammata.

Pasiardis, P. (2004). Ekpaideftiki igesia: Apo tin periodo tis evmenous adiaforias sti sygchroni epochi [Educational leadership: From the period of favorable indifference to the modern era]. Athina: Metaichmio.

Petroulakis, N. V. (1992). Programmata, Ekpaideftikoi stochoi, Methodologia [Programs, Educational goals, Methodology]. Athina: Grigori.

Pigiaki, P. (1999). Proetoimasia, Schediasmos kai Axiologisi tis Didaskalias. Didaktiki methodologia [Preparation, Design and Evaluation of Teaching. Teaching methodology]. Athina: Grigori.

Poulakou-Rempelakou, E. (2007). To paidi kai i ygeia tou sti Vyzantini epochi [The child and his/her health in the Byzantine era]. Archaiologia \& Technes, 103, 20-27.

Powell, R. G., \& Caseau, D. (2004). Classroom Communication and Diversity: Enhancing Instructional Practice. Mahwah, New Jersey: Lawrence Erlbaum Associates.

Pyrgiotakis, I. E. (2000). Eisagogi stin Paidagogiki Epistimi [Introduction in Pedagogical Science]. Athina: Ellinika Grammata.

Raptis, P. (1998). Mathitiki paravatikotita kai paidonomia stin elliniki ekpaidefsi kata ton $19^{\circ}$ aiona [Student delinquency and discipline methods in greek education during the $19^{\text {th }}$ century]. Nea Paideia, 86, 140-146.

Redl, F., \& Wineman, D. (1952). Controls from Within: Techniques for the Treatment of the Aggressive Child. New York: Free Press.

Rothstein, P. R. (1990). Educational Psychology. New York: McGraw-Hill.

Schunk, D. H., Pintrich, P. R., \& Meece, J. L. (2010). Ta kinitra stin ekpaidefsi [Motives in education]. Athina: Gutenberg.

Simopoulos, K. (1987). Vasanistiria kai exousia: Apo tin Ellinoromaiki archaiotita, to Vyzantio kai tin Tourkokratia os tin epochi mas [Torture and power: From Greco-roman antiquity, Byzantium and the Ottoman period to our era]. Athina. 
Slavin, R. E. (2006). Ekpaideftiki Psychologia. Theoria kai praxi [Educational Psychology. Theory and practice]. Athina: Metaichmio.

Smith, C. J., \& Laslett, R. (1993). Effective classroom management: A teacher's guide. London: Routledge.

Stovaios, I. (1995). Eklogai, Apofthegmata, Ypothikai [Elections, Quotations, Mortages]. Athina: Kaktos.

Taratori, E., Konsolas, M., \& Kougiourouki, M. (2007). To chioumor stin ekpaideftiki diadikasia: i optiki ton ekpaideftikon [The humor in the educational process: the teacher's perspective]. Kinitro, 8, 55-69.

Tsampis, G. X. (1999). I paideia sto christianiko Vyzantio [Education in christian Byzantium]. Athina: Grigori.

Tsourekis, D. G. (1987). Sygchroni paidagogiki: paidagogikes taseis apo tis arches tou $20^{\text {ou }}$ aiona mechri simera [Modern pedagogy: pedagogical trends from the early $20^{\text {th }}$ century until today]. Athina.

Tyler, K., \& Jones, B. D. (1998). Using the Ecosystemic Approach to Change Chronic Problem Behaviour in Primary Schools. Pastoral Care in Education, 16(4), 11-20. http://dx.doi.org/10.1111/1468-0122.00105

Vamvoukas, M. I. (1993). Eisagogi stin psychopaidagogiki erevna kai methodologia [Introduction to psycho-pedagogy research and methodology]. Athina: Grigori.

Xochellis, P. D. (1981). Paidagogiki tou scholeiou: Themata Koinoniologias tou Scholeiou kai Genikis Didaktikis [Pedagogy of school: Issues of Sociology of the School and General Didactics]. Thessaloniki: Adelfon Kyriakidi.

Xochellis, P. D. (1989). Ekpaidefsi kai ekpaideftikos simera: Provlimata kai prooptikes sti sygchroni ekpaidefsi [Education and teacher today: Problems and prospects in modern education]. Thessaloniki: Adelfon Kyriakidi.

\section{Copyright Disclaimer}

Copyright reserved by the author(s).

This article is an open-access article distributed under the terms and conditions of the Creative Commons Attribution license (http://creativecommons.org/licenses/by/3.0/). 